\title{
THE DUAL SCOPE OF THE REFUGEE CRISIS: HUMANITARIAN DISASTER OR A TERRORIST THREAT?
}

\author{
Leta BARDJIEVA MIOVSKA, PhD Candidate \\ Institute for Security, Defense and Peace, Faculty of Philosophy - Skopje \\ Email: Ibardjieva@gmail.com
}

\begin{abstract}
The refugee crisis remains a top priority topic for discussion and solution on the international scene. The dilemma remains whether the mass migration happening from Africa and Asia to Europe is a humanitarian issue, security threat, economic burden or all of the above. After the numerous media statements from several officials, experts and parties involved that ISIS is rapidly spreading through the refugees on their long and dangerous way across the world, the question remains opened, about the treatment, the status and the outcome of the refugee crisis. This paper will use the qualitative method of examining official statements and reports of the international community, stakeholders involved in this complex matter, politicians and NGO's about the actual situation on the field regarding the migrant crisis, as well as the quantitative data provided by relevant and reliable sources which depict the numbers of this issue when it comes to presenting the facts about the potential security threats, especially terrorism spreading through the migration camps and border lines.
\end{abstract}

Key words: migrant crisis, terrorism, security, securitization, humanitarian crisis.

\section{Introduction}

According to the European Commission, the world today is facing an unprecedented crisis of displacement. Currently, there are more than 65 million people which are forcibly displaced as a result of violent conflict or natural disaster in their homelands. ${ }^{30}$ Starting from 2015, the challenges about terrorist threats and the migrant crisis gain a certain degree of connection in public debates and on the political agenda. ${ }^{31}$

${ }^{30}$ European Commission (2016): Refugee Crisis in Europe. European Civil Protection and Humanitarian Aid Operations. http://ec.europa.eu/echo/refugee-crisis (accessed 29.05.2018)

${ }^{31}$ Crone, M. (2017): Europe's Refugee Crisis and the Threat of Terrorism: An Extraordinary Threat? DIIS Report 2017: 05. Copenhagen, Denmark. [online] (accessed 20.06.2018) http://pure.diis.dk/ws/files/910914/Report_05_Europes_ 


\section{Securrity}

From the moment when the Islamic state threated that it will radicalize and militarize the refugees and migrants through indoctrination with its ideals, the nexus which links refugees and terrorists was created, from which emanate two mainstream points of view and perceptions on migration and terrorism:

1. The refugees are vulnerable to radicalization and recruitment

2. The migrant routes are side doors for terrorists flows

According to the official information based upon which the general assessment and picture of the security condition in the $\mathrm{EU}$ is created regarding the mass flow of migrants and refugees and the terrorist attacks threats on European soil, these two finding can be reached:32

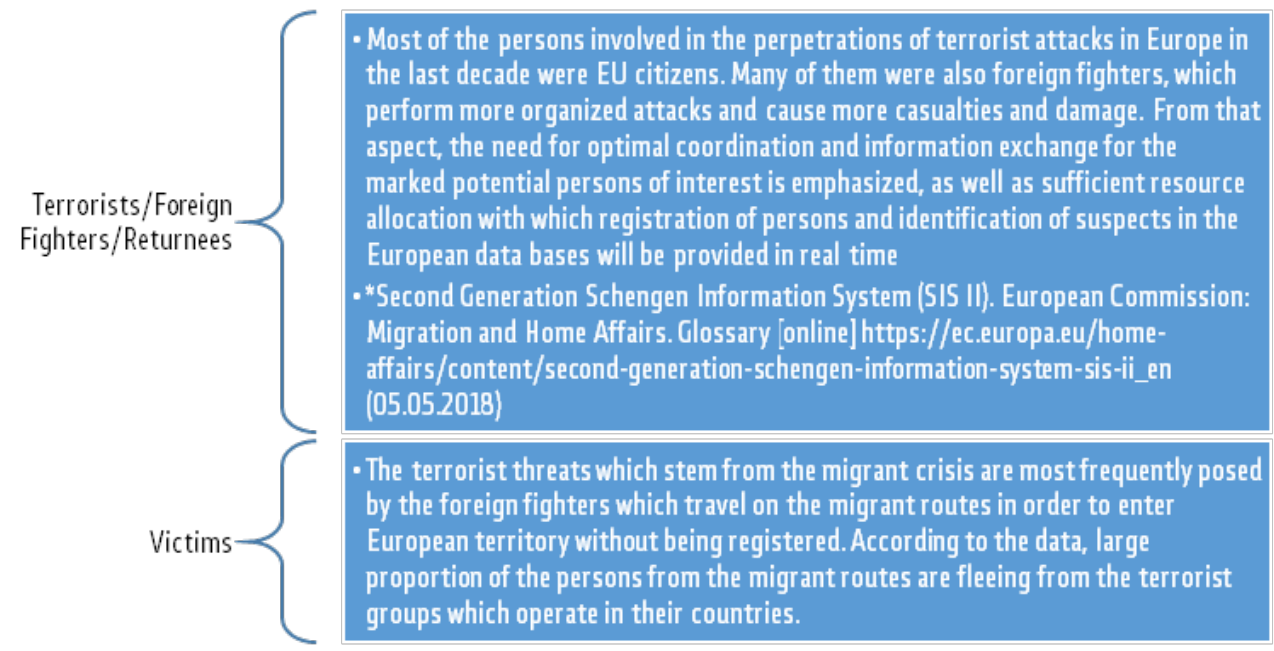

\section{The European Union Efforts}

In regard of the relation between the refugee and migrant crisis and terrorism, viewed through the lens of proper management, respectfully bringing political decisions and conducting activities for maintaining the security, the EU in the previous period since the migrant crisis became actual, has brought the following initiatives and measures:

- Establishing the European Counter Terrorism Centre in January 201633

- Extraordinary establishment of interim border control by some of the EU members

\footnotetext{
Refugee_Crisis_Web.pdf (15.03.2018)

${ }^{32}$ Refugee Crisis: Majority of Europeans Believe Increased Migration Raises Terror Threat, Survey Says. The Independent. [online] http://www.independent.co.uk/news/world/europe/refugee-crisis-asylum-seekers-europe-terrorism-terrorthreat-brexit-immigration-migrants-a7132256.html (15.03.2018)

33 Europol: European Counter- Terrorism Centre. European Union Terrorism Situation and Trend Report 2018 (TESAT 2018) [online] https://www.europol.europa.eu/crime-areas-and-trends/crime-areas/terrorism (accessed 28.05.2018)
} 
- The EU and Turkey Statement from March 2016, with which the EU is committed to pay Turkey $€ 3$ billion for facilitating refugees from Syria in Turkey through visa liberalization, social and health protection, as well as receiving all illegal migrants which transit Turkey and are headed toward the Greek islands; Turkey is obliged to undertake all the necessary activities for preventing the emergence of new terrestrial or maritime routes ${ }^{34}$

- Amplification of the Frontex authorities, agency which in October 2016 was renamed as the European Border and Coastguard Agency ${ }^{35}$

- Additional EU directive Passenger Name Record, which counterpoises a mechanism for detection, prevention and terrorism investigation, as well as other forms of serious crime used in the EU countries, as well as other countries for providing information on passengers by the air transporters. ${ }^{36}$

- Due to the increased challenges in regard of the migration management challenges, in the period from 2015-2018, the European Commission had allocated €22 billion. ${ }^{37}$

Table 1 and Table 2: EU Budget for the Refugee Crisis and Improving Migration Management. European Commission. https://ec.europa.eu/home-affairs/sites/homeaffairs/files/what-wedo/policies/european-agenda-migration/20171207_eu_budget_for_the_refugee_crisis_and_ improving_migration_management_en.pdf (accessed 12.10.2018)

Table 1

\begin{tabular}{|l|l|}
\hline Planned funding Inside EU & Total $€$ 9, 6 billion \\
\hline $\begin{array}{l}\text { AMIF (Asylum, Migration and Integration Fund), ISF } \\
\text { (International Security Fund), Emergency Support } \\
\text { Management }\end{array}$ & $€$ 8, 2 billion \\
\hline Emergency Funding & $€ 1,8$ billion \\
\hline Long Term Measures & $€$ 6, 4 billion \\
\hline Support to Agencies and their Operations & $€ 1,4$ billion \\
\hline
\end{tabular}

${ }^{*}$ EU Funding Inside and Outside the EU 2015-2018

\footnotetext{
${ }^{34}$ Implementation of Turkey-EU Agreement of March 18 2016. Ministry of Foreign Affairs, Republic of Turkey. [online] http://www.mfa.gov.tr/implementation-of-turkey_eu-agreement-of-18-march-2016.en.mfa

${ }_{35}$ Welcoming the European Border and Coast Guard Agency http://cdt.europa.eu/en/news/welcoming-europeanborder-and-coast-guard-agency

${ }^{36}$ Passenger Name Record (PNR) Directive (EU) 2016/681. European Commission. Migration and Home Affairs/Policies. [online] https://ec.europa.eu/home-affairs/what-we-do/policies/police-cooperation/information-exchange/pnr_en (20.05.2018)

${ }^{37}$ European Commission: EU Budget for the Refugee Crisis and Improving Migration Management. https://ec.europa. eu/home-affairs/sites/homeaffairs/files/what-we-do/policies/european-agenda-migration/20171207_eu_budget_ for_the_refugee_crisis_and_improving_migration_management_en.pdf (accessed 23.05.2018)
} 


\section{Security}

Table 2

\begin{tabular}{|l|l|}
\hline Planned Funding Outside the EU & Total: $€$ 12, 4 billion \\
\hline Humanitarian Aid & $€ 3,5$ billion \\
\hline $\begin{array}{l}\text { Support to Border and Migration Management in } \\
\text { Turkey and Western Balkans }\end{array}$ & $€$ 0,3 billion \\
\hline $\begin{array}{l}\text { Support to Livelihood Opportunities, Health, Educa- } \\
\text { tion for Refugees and Mobility Policy }\end{array}$ & $€ 0,8$ billion \\
\hline $\begin{array}{l}\text { Return of Refugees or Displaced Persons, Aid and } \\
\text { Support to Migrants, Fight Against Root Causes of } \\
\text { Migration }\end{array}$ & $€ 1,6$ billion \\
\hline $\begin{array}{l}\text { Support to Stabilization and Peace, Security and } \\
\text { Border Management of Third Countries }\end{array}$ & $€ 0,4$ billion \\
\hline Trust Fund for Syria (MADAD Fund) & $€ 0,6$ billion \\
\hline Facilities for Refugees in Turkey (FRIT) & $€ 1,0$ billion \\
\hline EU Emergency Trust Fund for Africa & $€ 2,6$ billion \\
\hline $\begin{array}{l}\text { Pledges from the London Conference Feb. 2016 and } \\
\text { the Brussels Conference Apr. 2017 Supporting the } \\
\text { Future of Syria and the Region }\end{array}$ & $€ 1,6$ billion \\
\hline
\end{tabular}

In order to undertake a comprehensive approach toward managing the refugee crisis in the EU, the European Commission has brought the European Agenda for Migration, which designates the numerous tools and instruments at disposal on an EU level and in the member states solely, tackling the migrant crisis and refugees flows, as well as prevention of further loss of lives at sea or at land in joint search and rescue operations. ${ }^{38}$

1. One of the instruments is the emergency support funding which is available for the member states which face overwhelming of their response capacities, due to urgent and exceptional circumstances, like the sudden influx of refugees. This assistance is complementary with the actions of the member states and it is provided in close coordination with the concerned countries, as well as the humanitarian partner organizations of the Commission, including the agencies of the UN, as well as international and non-governmental organizations. This funding can be utilized for providing basic needs such as food, shelter and medicine.

2. The second instrument of the Commission's EU relief assistance through the

\footnotetext{
${ }^{38}$ European Commission: Migration and Home Affairs: European Agenda for Migration [online] https://ec.europa.eu/ home-affairs/what-we-do/policies/european-agenda-migration_en (28.05.2018)
} 
Directorate-General for European civil protection and humanitarian operations (ECHO) is civil protection offered to about 120 million people in need annually. ${ }^{39}$

3. The third instrument of the European Commission is humanitarian aid operations which enable rapid and effective delivery of the EU relief assistance.

The medium term effects from the European Agenda for Migration, after undertaking structural actions and priorities founded on four pillars consist of:

1. Reducing the incentives for irregular migration: the focus is on addressing the root causes behind irregular migration in non-EU countries, dismantling smuggling and trafficking networks and defining actions for the better application of return policies.

2. Saving lives and securing the external borders: this involves better management of the external border, in particular through solidarity towards those Member States that are located at the external borders, and improving the efficiency of border crossings.

3. Strengthening the common asylum policy: with the increases in the flows of asylum seekers, the EU's asylum policies need to be based on solidarity towards those needing international protection as well as among the EU Member States, whose full application of the common rules must be ensured through systematic monitoring.

4. Developing a new policy on legal migration: in view of the future demographic challenges the EU is facing, the new policy needs to focus on attracting workers that the EU economy needs, particularly by facilitating entry and the recognition of qualifications.

The migrant and refugees wave has a significant impact on transiting countries as well, beside the Northern and Western European Union countries which pose a final destination on the migrant routes. Such countries include Greece, Turkey, Libya, Italy, etc., for which in certain situations the national capacities for managing emergency situations were not able to completely respond.

\section{Humanitarian disaster}

\section{[accessed}

$\overline{{ }^{9} 9}$ European's Commission Directorate General for European Civil Protection and Humanitarian Aid Operations. [online] https://reliefweb.int/organization/echo (29.05.2018) 


\section{Secuurity}

According to the data from the UNHCR, until April 2018, more than 13, 1 million Syrians had been in need, from which 5, 6 million sought refuge in the neighboring countries Lebanon, Jordan and Turkey since the start of the Syrian conflict in 2011. Within Syrian territory, there are 6, 6 million internally displaced people, and 2, 98 million in remote and besieged areas. Many of the people which arrived in the EU from 2015 until now had been through a dangerous journey on sea, land and air, many of them were in dire need of basic humanitarian assistance, such as pure potable water, health protection, accommodation and legal assistance. Additionally, many of the persons arriving were unaccompanied children which have special protection needs and status during arrival and transit.40

These people have escaped across border wires, fleeing bombs and bullets that have destroyed their homes and avoided chemical weapons attacks which decimated their families. Turkey is a host of the largest proportion of the Syrian refugees, which accounts to 3, 3 million. The vast majority of Syrian refugees settled in the neighboring countries lives in urban areas, and about $8 \%$ of the total number of refugees are accommodated in refugee camps. For instance, around million Syrian refugees in Lebanon are left with little or no financial resources, and around $70 \%$ of them are living below the line of poverty. Formally there are no designated refugee camps, and Syrian refugees can be found living in more than 2000 urban and rural locations and communities, where they often share small basic lodgings with other refugee families in unsatisfactory conditions.

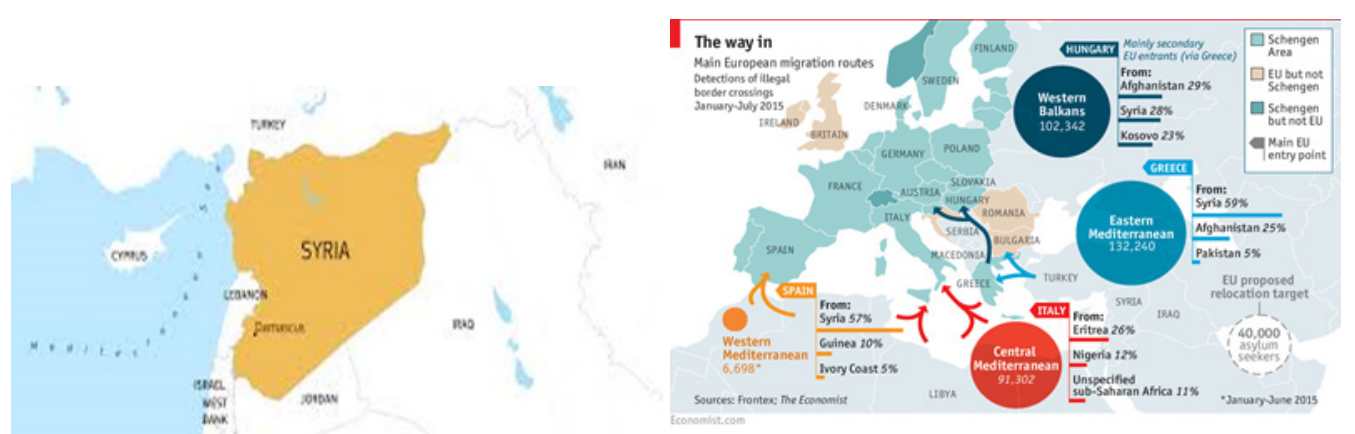

Picture 1: Syria and the Neighboring Countries. European Civil Protection and Humanitarian Aid Operations. Factsheet: https://ec.europa.eu/echo/where/middle-east/syria_en

Picture 2: Main Migrant Routes January-July 2015 Herblay, L.: Ce que révèle l'effarant accord sur les migrants entre l'UE et la Turquie. 21 March, 2016.

https://www.agoravox.fr/

40 In 2016, 14\% from the persons which arrived in Italy through the Mediterranean were unaccompanied children. Migration Data Portal. [online] https://migrationdataportal.org/data?i=REforiginunder18\&t=2015 laccessed 29.05.2018) 


\section{Terrorism threat}

Homegrown terrorism and violent extremism, together with foreign fighters and returnees transiting through the migrant routes from Africa and the Middle East, through the Western Balkans and East Mediterranean routes to Western and Northern Europe has been a major priority to security and intelligence activities, in parallel with the terrorist attacks which occurred on European land and had tragic consequences, as well as the increase and intensification of digital radicalizations. ${ }^{41}$

From the assessments and analysis based on official and intelligence data, over various aspects and determinants in regard of the connection between the migration and refugee crisis and the emergence of potential terrorist threats, scoping the political situation, the level of security in means of existence or nonexistence of violent or nonviolent conflict, geographic specifics, economic and environmental conditions, etc., the common general notion and opinion that the migrants are directly related with a terrorism threat and the possibility for their radicalization is likely to occur.42 Certain politicians such as Hungary's Prime Minister Viktor Orban have utilized such statements to the maximum, describing refugees and migrants as "the Trojan horse of terrorism." 43

The facts and figures on foreign fighters from the Western Balkan in particular, which are joining Daesh and Al Nusra most frequently in Iraq and Syria, as well as on both sides of the Ukraine conflict, after certain investigations on weapons used in terrorist attacks in Western Europe which had shown origin from the region, as well as reports on Islamic fundamentalism on the rise (yet homegrown, rather than imported), had instigated a broader and strengthened antiterrorist efforts in the region and increased intelligence cooperation by the EU. ${ }^{44}$

\footnotetext{
${ }^{41}$ Crisp, J.: Refugees: the Trojan horse of Terrorism? Can Europe Make it? Open Democracy. 5 June 2017 [online] https:// www.opendemocracy.net/can-europe-make-it/jeff-crisp/refugees-trojan-horse-of-terrorism (03.05.2018)

${ }^{42}$ Zakem, V., Rosenau, B., Johnson, D.: Shining a Light on the Western Balkans. May 2017 [online] https://www.cna.org/ cna_files/pdf/DOP-2017-U-015223-2Rev.pdf (27.05.2018)

43 European Citizens, Not Refugees, Behind Most Terrorist Attacks in Europe. DIIS Report, Danish Institute for International Studies. June 212017 [online] https://www.diis.dk/en/research/european-citizens-not-refugees-behindmost-terrorist-attacks-in-europe (03.05.2018)

44 Lange, S.: Tackling Common Challenges at 2017 Western Balkans Summit: Security, Migration, Terrorism. Italian Institute for International Political Studies. 10 July 2017 [online] https://www.ispionline.it/en/pubblicazione/tacklingcommon-challenges-2017-western-balkans-summit-security-migration-terrorism-17178
} 


\section{Securitity}

Table 3 Western Balkans Foreign Fighters and Returnees: STRATPOL, January 2018, http:// stratpol.sk/wp-content/uploads/2018/01/_Returnees_Western_Balkans_Stratpol_pdf

\begin{tabular}{|l|l|l|l|l|l|l|}
\hline Country & Total & Women & Children & Returned & Killed & In conflict \\
\hline & & & & & & \\
\hline Albania & 136 & 13 & 31 & 40 & 20 & 76 \\
\hline $\begin{array}{l}\text { Bosnia and } \\
\text { Herzegovina }\end{array}$ & 260 & 56 & 80 & 43 & 44 & $\begin{array}{l}77 \text { men, 48 } \\
\text { women, 46 } \\
\text { children }\end{array}$ \\
\hline Kosovo & 316 & 38 & 28 & 118 & 59 & $\begin{array}{l}139 \text { (75 } \\
\text { men, 38 } \\
\text { women, 27 } \\
\text { children) }\end{array}$ \\
\hline Macedonia & 135 & - & - & 80 & 27 & 35 \\
\hline Serbia & 42 & - & - & 9 & 11 & 28 \\
\hline montenegro & 30 & - & - & - & 5 & - \\
\hline
\end{tabular}

For comparison, in 2015, the number of foreign fighters in ISIS from the Balkans in Iraq and Syria was 90 people from Albania, 340 from Bosnia and Herzegovina, Kosovo had 150 citizens recruited as foreign fighters, Macedonia 12, and Serbia 70 persons. ${ }^{45}$

The common link connecting the EU and the Western Balkans is threaded on three main issues: security, migration and terrorism, which contributed for closer ties knotted with the security sector all across the region, from the aspect of migration and refugees wave management as well as increased border security cooperation in order to support these three issues. ${ }^{46}$

These issues defined as threats combine several different aspects which form a single weapon against Europe: illegal immigration, lack of integration, social malaise in poor urban peripheries, extremist Islamist ideology as well as the presence and transit of returning fighters from the crisis areas.

\footnotetext{
45 NATO Parliamentary Assembly. Mediterranean and Middle East Special Group. ISIL/Daesh and Al Qaeda Threat to Europe. 23 November 2017 [online] https:/www.nato-pa.int/download-file?filename=sites/default/ files/2018-02/091\%20GSM\%2017\%20E\%20rev.2\%20fin \%20-\%20ISIS\%20DAESH\%20THREAT\%20T0\%20 EUROPE\%20-\%20MANCIULLI\%20REPORT.pdf

${ }^{46}$ Grizold, A., Skočajič, J., N.: The Complex of Security in the Western Balkans: Processes and Issues. Teorija in Praksa. Let. $542 / 2017$
} 


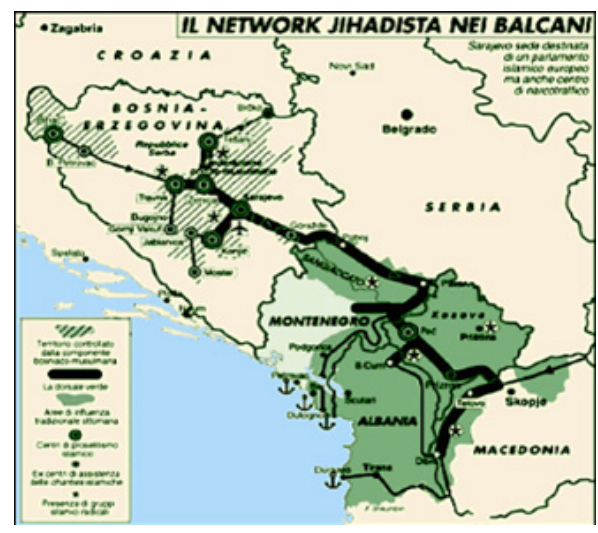

Picture 3: Jihadist Movement Route. The Green Corridor in the Balkans/ Islamist Activities since 2008* Western Half of the Green Corridor. http://acdemocracy.org/our-goal-is-jerusalemmilitant-islamists-in-southeast-europe/

If efficaciously exploited, each of these destabilizing factors for emergence of international terrorism counterpoise an opportunity to attack. ${ }^{47}$

Still, contrary to these assumptions, the number of refugees which perpetrated a terrorist act is insignificant, as reported by an exhaustive study by the Cato Institute. ${ }^{48}$ Extremist organizations have themselves been eager to perpetuate this frightening scenario, as when the Islamic State declared that 4,000 of its members had been infiltrated into Europe under the cover of the refugee influx. ${ }^{49}$

\footnotetext{
${ }^{47}$ European Commission. Refugee Crisis in Europe. http://ec.europa.eu/echo/refugee-crisis (25.05.2018)

${ }^{48}$ Levenson, E.: How Many Fatal Terror Attacks Have Refugees Carried Out in the US? None. CNN 29 January 2017. [online] https://edition.cnn.com/2017/01/29/us/refugee-terrorism-trnd/index.html (03.05.2018)

49 Kiely, E.: Refugees and Terrorism Investigations. The Wire, March 10, 2017 [online] https://www.factcheck. org/2017/03/refugees-and-terrorism-investigations/ (03.05.2018)
} 


\section{Security}

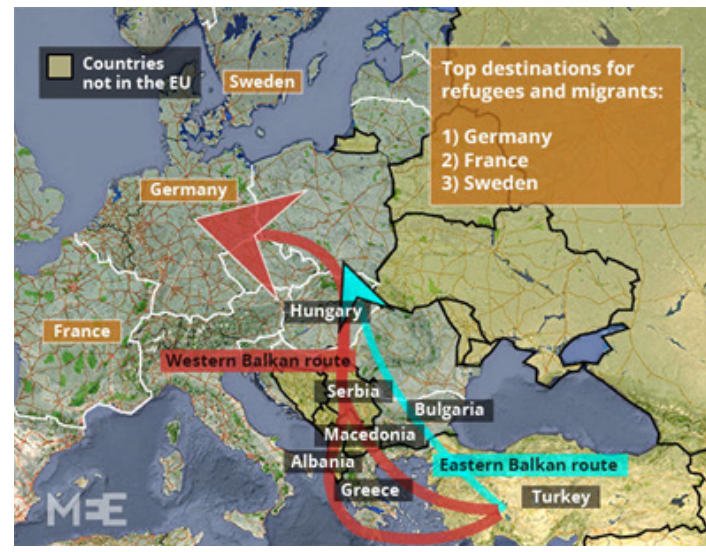

Picture 4: Western Balkan Route. Notes on the Emergent Western Balkan Route of Migrants. http://demographymatters.blogspot.com/2015/06/notes-on-emergent-western-balkan-route. html

Since 2011, it is estimated that about 40000 foreign fighters had gone in the conflicts in Iraq and Syria, their nationalities were from 110 different countries, from which around 1000 were from the Western Balkans fighting in the wars of Syria and Iraq between the period of 2012 and $2016 .{ }^{50}$

\section{The Case with the Republic of Macedonia}

During 2015 and in the first several months of 2016, the Republic of Macedonia had faced with a great number of refugees and migrants which transited over its territory on their way to the northern and western European countries. The migrant and refugee flow had at least two important dimensions which demanded undertaking urgent measures:

1. The humanitarian dimension

2. The security dimension

From a humanitarian point of view, there is an immediate need for providing a safe passage through the territory of the Republic of Macedonia for the migrants and refugees which are determined to reach the countries in Western and Northern Europe, as well as to provide clear and simple procedures for granting asylum to refugees and migrants which seek asylum in the Republic of Macedonia.

\footnotetext{
${ }^{50} \mathrm{https}$ ://icct.nl/wp-content/uploads/2018/05/ICCT-Bos-VanGinkel-Mehra-Capacity-Building-Challenges-May-2018. pdf (28.05.2018)
} 
The national security notion in the migrant crisis emphasizes the need to establish control over the points of entrance and exit of the migrants and refugees (which mainly enter and exit Macedonian territory outside the legal national and international border passages), with the appliance of proper registration measures. The border control registration procedure counterpoises both one of the core aspects of preserving national security and providing humanitarian assistance, in order to decrease the risk from migrant and refugee exploitation by local and regional human trafficking networks, which subsequently refers to the security of the migrants/refugees. In order to respond properly to every dimension of the migrant crisis, the Republic of Macedonia has undertaken numerous measures, which primarily include altering the legislature and adopting adequate mechanisms for migration policies, relying both on its own resources and on the cooperation with several countries from the Southeastern Europe and wider. ${ }^{51}$ There is a broadly accepted point of view by the expert community in the Republic of Macedonia, that just as the other countries from the Western Balkans migrant corridor, through which more than a million refugees and migrants had crossed, had been affected by numerous challenges primarily: illegal migration, trans-border crime, and terrorist threats.

As a retrospective, in the last quarter of a century the Republic of Macedonia had been facing similar challenges with refugee and migrant crisis. Ever since it gained its independence in 1991, the country had felt the impacts from the political and economic instability of its neighboring Albania, the subsequent first democratic elections and the mass migrations and departures from Albania, when about 1200 persons from the border regions with Macedonia demanded protection and were taken care of. During 1992 the Republic of Macedonia has hosted 35000 persons which were fleeing the war in Bosnia and Herzegovina. In spring 1999 it was the Kosovo crisis which caused more than 300000 people to seek international protection in Macedonia. ${ }^{52} \ln 2001$, as a result of the armed conflict in Macedonia, 86, 954 people were internally displaced. ${ }^{53}$

Facing the serious flow of migrants and refugees, the Republic of Macedonia had declared a state of emergency on August 19th 2015, which was extended to December 31st 2017. More than one million people had went on the territory of the Republic of Macedonia as a part of the Balkan route in order to get to the countries in Western and Northern Europe. This refugee/migrant crisis had a primarily transit character, yet the country and the citizens of the Republic of Macedonia were witnessing eventual consequences of security, economic, political and humanitarian nature. $^{54}$ On the Western Balkans corridor, according to the National Coordinative center for

\footnotetext{
${ }^{51}$ Ефектите на мигрантската криза во земјите од Југоисточна Европа. Парламентарен институт. Скопје,

јули 2016. [online] https://www.sobranie.mk/content/\%D0\%9F\%D0\%B0\%D1\%80\%D0\%BB\%D0\%B0\%D0\%BC\%

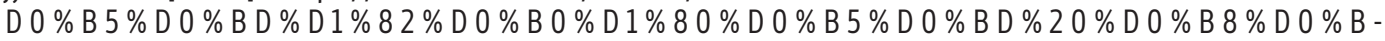

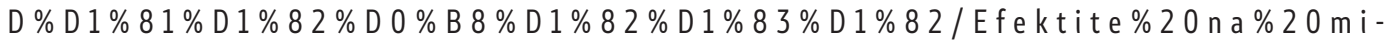
gratskata\%20kriza\%20vo\%20zemjite\%20na\%20JIE\%20-\%20MK.pdf

(25.05.2018)

${ }_{52}$ CNN: More Kosovo Refugees flown out of Macedonia. April 6, 1999 [online] http://edition.cnn.com/WORLD/ europe/9904/06/kosovo.refugees.01/

53 Што презема Македонија во справување со мигрантската криза? https://www.mkd.mk/kolumni/shto-prezemamakedonija-vo-spravuvanje-so-begalskata-kriza

${ }^{54}$ Дебата за јакнење на капацитетите и ресурсите во услови на мигрантска криза на Западен Балкан. https://www.
} 
border management of the Republic of Macedonia, more than 800000 people have crossed, from which more than 120000 were children. About 3000 people had unfortunately lost their lives on their way to their final destination. ${ }^{55}$

The route is now officially closed, but there still are attempts for illegal crossing on a daily basis. As stated by the National Coordinative center for border management of the Republic of Macedonia, during the previous migrant and refugee flux, Macedonia had faced a security risk, respectfully, risks of radical Islam returnees which originate from the region, as well as public health hazards, due to the fact that many of the people which were fleeing from the war affected countries were also potential diseases carriers such as Ebola, malaria, morbilli measles, etc.

\section{Conclusion}

Whether the refugee crisis is viewed as a security threat which requires a solely security response in order to be managed, or viewed as a humanitarian disaster which has to be mitigated and alleviated by means which involve application of the international humanitarian procedures, this issue remains high on the agendas in the national governments and international organizations.

The efforts directed toward prevention of refugee and migrant influx concerted by the national governments of the affected countries and the organizations of the international community, (emphasizing the resources and funding diverted toward border management and registration, asylum, humanitarian aid including food, water and medicine supplies, as well as housing and employment) had brought to a certain level of alleviation and facilitation of the migrant and refugee crisis in terms of providing basic humanitarian assistance and maintaining the security of the involved.

As concluded by the information and data at disposal for this particular issue, there was a significant degree of mobilization by the relevant bodies which were designated to respond to this contemporary humanitarian and security crisis. Even if now when there are no evident mass movement and flow on the borders on the transiting countries and the EU states, given the nature of this complex issue, there are still many aspects which need to be realized for overcoming the medium term and long term implications and consequences by this concern.

What can be assessed as a conclusion is there is still more to be done, by the national governments and international organizations, primarily in the context of coordination, intelligence and information sharing between designated bodies, standardized methods and procedures and other constructive means for resolving this issue, since it has a multi-national layer of involved parties. The NGO's which have shown that they are a worthy stakeholder in the concrete issue need to be included as well in the information sharing circle, since their activities are on the ground in

akademik.mk/debata-za-jaknene-na-kapatsitetite-i-resursite-vo-uslovi-na-migrantska-kriza-na-zapaden-balkan/

55 Национален кооординативен центар за гранично управување. [online] http://www.igu.gov.mk/?q=node/9 (29.05.2018) 
the center of the events, which can be useful in countering human trafficking, illegal smuggling of immigrants, as well as terrorism threats and elements of extremism.

Elimination of the root causes for violent conflicts in the affected areas from where the migrants and refugees are leaving, providing satisfactory living conditions for the taken migrants and refugees, including accommodation, sustainable economic solutions and integration in the communities, prevention of radical extremism occurrences, border controls and management mechanisms for counter-terrorism, registration and security checks for seizing foreign fighters and returnees, human trafficking, illegal arms trades and drug smuggling, and other serious crimes distinctive for the migrant and refugee crisis.

Along with adjustment of the legislature both national and international, regarding the management of the migrant and refugee flows in direction of enabling both humanitarian assistance and preventing security threats, significant alternations were made in order to properly respond to this situation.

Hence, the dual scope of the refugee crisis is the indicator which emphasizes the multi layered nature of the issue, which is an ongoing process, with tendencies for further continuation, and regional and international implications over the political, security, economic and social trends and shifts. The instruments and tools vary in different countries on a national level, as well as the approach of the international community, having in mind the EU, the UN, the International Federation of the Red Cross and Red Crescent primarily, but many other actors are included, such as private companies and entrepreneurships, etc., and the main foundations for development of the response are based on the assumptions that the refugee crisis is a back door for extremism and terrorism flow and needs to be managed with security measures and that the refugee crisis is a humanitarian disaster with economic and social features and needs to be facilitated with social and economic means.

Also significant to denote, the media on a national and international scale, has a portion of the influence and creation of the attitude and opinions in the public for the nature of the migrant crisis. In concrete, the info broadcasted in the coverage of the news regarding the refugee crisis have to impartial and neutral, in accordance with media ethics and principles, withholding from spreading panic and propaganda for the specific topic.

Both patterns of engagement need to abide to the international code of conduct for humanitarian assistance, the fundamental human right of passage and asylum seeking, as well the other human rights which need to be respected in the matters of the migrant crisis management. 


\section{Securitity}

\section{Literature:}

1. Akkerman, M. (2018): Expanding the Fortress. The Policies, the Profiteers and the People Shaped by EU's Border Externalization Program. Transnational Institute, Amsterdam.

2. Baldaccini, A. (2010): Extraterritorial Border Controls in the EU: The Role of Frontex in Operations at Sea. Human Rights and Humanitarian Law E-books on-line. Volume 21.

3. Celata, F., Colleti, R. (2015): Neighborhood Policy and the Construction of the European External Borders. Geo Journal Library, 115. University of Rome La Sapienza. Springer, Rome.

4. Developing European Internal Security Policy: After the Stockholm Summit and the Lisbon Treaty. Routledge, Taylor \& Francis.

5. Gebrewold, B. (2016): Africa and Fortress Europe: Threats and Opportunities. Routledge, London and New York.

6. Geyer, F. (2008): Security versus Justice: Police and Judicial Cooperation in the European Union. Routledge, London.

7. Kaunert, C., et al (2015): Supranational Governance of Europe's Area of Freedom, Security and Justice. Routledge.

8. Monar, J. (2016): Cooperation in the Justice and Home Affairs Domain: Characteristics, Constraints and Progress. Journal on European Integration. Volume 28, Issue 5.

9. Mungianu, R. (2016): Frontex and Non- Refoulement: The International Responsibility of the EU. Cambridge University Press.

10. Sirkeci, I. et al (2016): Conflict, Insecurity and Mobility. Transnational Press London.

11. Vallet, E.: Borders, Fences and Walls: State of Insecurity? Routledge.

\section{Online:}

1. European Commission: European Agenda on Migration https://ec.europa.eu/homeaffairs/what-we-do/policies/european-agenda-migration_en

2. The UN Refugee Agency http://www.unhcr.org/syria-emergency.html

3. Migration Data Portal https://migrationdataportal.org/themes/child-migrants-0

4. Fisher, J., Bela, M.,Pavicic, V: ISIS Threat in the Balkans. https://www.chds.us/ed/resources/ uploads/2015/12/Summit-2015-Fisher-Bela-Pavicic-ISIS-Threat-in-the-Balkans.pdf

5. Mancuilli, A.: NATO Parliament Assembly Report. www.nato-pa.int

6. European Commission: Managing the Refugee Crisis. Western Balkan Routes: State of Play Report. https://ec.europa.eu/home-affairs/sites/homeaffairs/files/what-we-do/ policies/european-agenda-migration/background-information/docs/western_balkans_ route_state_of_play_report_en.pdf

7. European Union Institute for Security Studies (EUISS): Beslin, J., Ignjatijevic, M.: Balkan Foreign Fighters: From Syria to Ukraine. June 2017 https://www.iss.europa.eu/sites/ default/files/EUISSFiles/Brief\%2020\%20Balkan\%20foreign\%20fighters.pdf 
8. Zakem, V., et al.: Shining a Light on the Western Balkans. CAN May 2017. https://www.cna. org/cna_files/pdf/DOP-2017-U-015223-2Rev.pdf

9. U.S. Department of State, Factsheet on the Balkans. https://www.state.gov/p/eur/rt/ balkans/

10. Strategic Policy Institute. http://stratpol.sk/ 